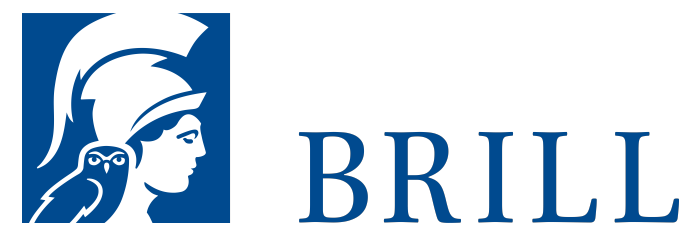

\title{
Preaching after Easter: Mid-Pentecost, Ascension, and Pentecost in Late Antiquity
}

Editors: Richard W. Bishop, Johan Leemans, and Hajnalka Tamas

The studies collected in Preaching after Easter examine the festal history and homiletics of Mid-Pentecost, Ascension, and Pentecost in the late antique Mediterranean world. Articles on individual sermons or the work of individual preachers such as John Chrysostom, Augustine of Hippo, Peter Chrysologus, Leo the Great, and Severus of Antioch exhibit the richness of late antique festal preaching. Questions of authenticity, heresiology, and theological, exegetical, or liturgical history are addressed with methodological rigor. Complementary contributions that deal with ancient Jewish-Christian dialogue, art-historical reception, and contemporary liturgical theology illustrate the wide ramifications of ancient Christian festal practice. Students and scholars of these feasts and the interpretive traditions devoted to them will find this volume to be an indispensable source of information and analysis.

\section{Readership}

This volume is of interest to students and scholars doing research on late antique liturgical history, sermon studies, patristic theology and exegesis, textual criticism and art history.

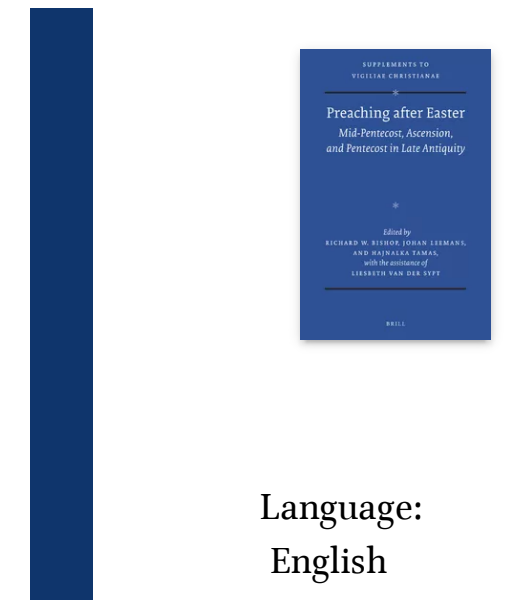

Subjects: Early

Church \&

Patristics,

Biblical Studies,

Greek \& Latin

Literature,

Classical

Studies, Church

History, History,

Religion in

Antiquity,

Religious

Studies

Publisher: Brill

Series:

Vigiliae

Christianae,

Supplements,

Volume: 136

E-Book (PDF)

Released online:

21 Jun 2016

ISBN: 978-90-

04-31554-9

List price

USD \$208.00

Hardback

Publication date:

ogJun 2016 
Richard W. Bishop (Ph.D. 2009) is a post-doctoral fellow at the 04-31553-2 List price Faculty of Theology and Religious Studies, KU Leuven (Belgium). His current project is an annotated translation of the extant Greek festal sermons on Ascension and Pentecost from Late Antiquity.

Prof. Dr. Johan Leemans (Ph.D. 2001) is full professor of Christianity in Late Antiquity at the Faculty of Theology and Religious Studies, KU Leuven (Belgium). He has published extensively on late antique sermons and on the theology of the Cappadocian Fathers.

Dr. Hajnalka Tamas (Ph.D. 2014) is a post-doctoral fellow of the Fritz Thyssen Stiftung and research associate at the Faculty of Theology and Religious Studies, KU Leuven (Belgium). Her research interests include late antique hagiography and asceticism.

For more information see brill.com

Order information: Order online at brill.com +44330 3330049 | customerservices@brill.com Submission information: brill.com/authors

Titles published by Brill | Fink, Brill | mentis or Brill | Schöningh: +49(o)71 5413279216 | brill@brocom.de 